\title{
TOWARD A TYPOLOGY OF BENEFIT-GRANTING IN ISLAM*
}

\author{
Kazuo Ohtsuka**
}

\section{Issue}

As many scholars studying the history or the sociology of Japanese religion have pointed out, one of the distinctive characteristics of the Japanese magicoreligious phenomena, especially those of folk belief and cults, is a strong orientation to or emphasis on this worldly rewards from deities rather than those directed to the hereafter. Japanese generally believe in diverse dieties worshipped in various popular cults ranging from the custom of the occasional visiting to Shinto shrines or Buddhist temples to a devoted affiliation with various religious sects, mainly because they seek to obtain some divine benefits, which assure a peaceful and healthy life in general, guarantee some success such as a success of examinations in a school, and relieve some troubles such as a physical or mental illness or a barrenness. They approach deities in shrines or temples, or the leader of the sect, who is often venerated as a living-god, in order to receive some benefits in this world. In short, a believer is thought to carry out a transaction with his divine, in which he devotes himself to the deities or gods who in turn give him some benefits as a reward for his sincere devotion. As a researcher on the social anthropology of Islam, who has grown up in a Japanese cultural setting, I like to propose here a question, whether we could find a similar phenomenon in Islamic world, that is, a kind of a transaction between divine beings and muslims.

Islam, which is rightly considered as one of the great monotheistic religions in the world, formally commands believers (muslimün) to submit totally to only one God, Allah, who is the Omnipotent and the Creator of the universe. Then it seems that there is left no room for a transaction or in a negotiation with Him,

* This paper is a revised version of my paper in Japanese, "On the idea of 'the-benefitgranted-in-this-world' in Islam" originally printed in Orient (Bulletin of the Society for Near Eastern Studies in Japan) vol. 29 no. 1, 1986.

** Research Fellow, National Museum of Ethnology, Osaka.

Vol. XXIV 1988 
and men only have to follow absolutely to His sacred order revealed in the Qur'ān and shown in the Hadīth, that is, the records of the sayings and behaviors of the Prophet Muhammad, who is considered to be the most perfect human being.

However, turning our perspective from examining theologically an Islamic formal doctrine to analyzing, sociologically, the daily practices of Muslims, we can find out that some Muslims manage to negotiate with Allah or some divine beings, especially Muslim saints (awliy $\bar{a}^{\prime}$ ), for obtaining some benefit from them. Sometimes they succeed to receive a divine benefit in this world, which reminds us of similar practices toward the deities in Japanese popular cults. The main purpose of this paper, therefore, is to investigate some aspects of the interactions between Islamic divine beings and Muslims from a perspective of the sociology of an exchange and to construct a typology of benefit-granting in Islam.

\section{Benefit Granted from Allah}

We start to carry out a content analysis of the Qur'ān to assure that there are some sorts of benefits which Allah may give to the pious Muslims in this world as well as in the hereafter. In the Qur'ān, thawäb is one of the words which could be translated as a "benefit". This word is used in thirteen sentences of nine chapters (süra-s). Examining what it means in each context, we could notice two of them suggesting a happy life in a paradise (3-195 and 18-31).(1) Unless this "paradise" could be interpreted as a metaphor of a prosperity in this world, these benefits will be certainly given in the hereafter. Although some thawa $\bar{a} b$-s (28-80, 18-44 and 18-46) do not suggest when and where they will be given to the pious, it could be understood from the contexts of these words that they should be granted in the hereafter, since they stand in contrast with a prosperity and wealth in this world.

On the other hand, there are the thawäb-s relating to both this and the other world in the Qur'an: "And whoso chooseth the reward of this world, we will give him thereof: but whoso chooseth the reward of the world to come, we will give him thereof." (3-145), "And God gave them the reward of this world, and a glorious reward in the life to come." (3-148) and "Whoso desireth the reward of this world, verily with God is the reward of this world, and also of that which is to come." (4-134). Generally speaking, a thawäb granted to a man 
by Allah is either a benfit to a devout man or a punishment to a wrongdoer. In these cases cited above, it is obvious from the contexts that Allah gives a good reward to a sincere believer, especially the thawāb in 3-148 which would be given to a fighter for the Islamic cause. As a result of examining a meaning of thawa $\bar{b}$ found in the Qur'ān, it could be suggested that, though most thawāb-s are granted in the hereafter, the pious may receive it in this world in a few cases.

The other word which can be also translated as a benefit is ajr. It is found more than a hundred times in the Qur'ān, though some of them do not have the meaning of a benefit granted from Allah. For example, ajr-s in 4-24, 4-25, 5-5, 33-50 and 60-10 have the meaning of bride-wealth as a more popular word, mahr, does. In the cases of ajr which Allah gives to a human being, it is not clear whether most of them are to be granted in this world or the hereafter. Some $a j r$-s (3-136, 12-57, 18-30, 29-58 and 39-74) may be interpreted as a divine gift in the hereafter. However we find a sentence in $16-41$ that although the emigrants who had fled from Mecca and settled in Medina with the Prophet were given a comfortable habitation, they would be granted an ajr in the hereafter, which is bigger (akbar) than that granted in this world. Consequently it is reasonable to suggest that the good habitation they obtained in Medina is a kind of ajr though it is even less than that in the hereafter.

There are three cases of ajr which we may decisively interpret as a reward in this world, moreover. Those are found in 12-56, 12-90 and 29-27. It is noteworthy here that the first two ajr-s suggest Yusef's holding of power in Egypt and the third one would be given to Ibrahim, Ishaq and $\mathrm{Ya}^{\mathrm{c}} \mathrm{qub}$, namely, they were special gifts granted to the prophets whom Allah had summoned. It is clear now that all receivers of the ajr in this world are divinely chosen people such as prophets or the emigrants with the Prophet Muhammad, not ordinary persons. With this restriction, it is safe to say that in the Qur'ān a benefit could be granted to the pious persons in this world. Based on the analysis of meaning of both thawāb and ajr, we can arrive at a conclusion that an idea of granting a benefit to a good Muslim in this world may be included as a legitimate tenet of Islam.

\section{An Exchange Theory as an Analytical Framework}

From the argument in the last section, it is proved theologically to be a fact that Allah can grant a benefit to a pious believer in this world. Locating

Vol. XXIV 1988 
this fact in wider socio-cultural contexts, we try to make its significance much clearer from a sociological or an anthropological perspective. In the following analysis, a divine benefit will be considered to be an essential element of a reciprocal exchange between a divinity and a believer.

The idea of introducing an exchange theory to a god-man relationship has been attempted in many works such as Mauss's classical essay [1923-4], in which an animal sacrifice or a valuable offering to a divinity had been regarded as a gift imposing a return on its receiver. Generally speaking, a first gift may become a starting moment for a continuous reciprocal exchange between the two.

Islam seems to be one of the most suitable cases to be analysed from a perspective of an exchange theory, since in the Qur'ān there are many metaphors of trade activities or commercial transactions representing various relations between Allah and men. Besides a reward (thawāb and ajr) mentioned early, we can easily find such verses in the Qur'ān as "Moreover, he whose balance shall be heavy with good works, shall lead a pleasing life: but as to him whose balance shall be light, his dwelling shall be the pit of hell." (101-6 9), or "And whoever shall have wrought good of the weight of an ant, shall behold the same. And whoever shall have wrought evil of the weight of an ant, shall behold the same." (99-7 8). And "Verily they who read the book of God, and are constant at prayer, and give alms out of what we have bestowed on them, both in secret and openly, hope for a merchandise which shall not perish" (35-29). Moreover it is said in the Qur'ān that two angels located on both shoulders of a man register all the right and the wrong he has done $(50-17 \sim 18)$ and this religious "balance sheet" would be taken into account when Allah ultimately decides his fate on the Day of the Judgement.

It is possible to suggest that, because the cradlelands of Islam, Mecca and Medina, were flourishing centers of commerce and trade when Muhammad started his religious propaganda and the Prophet himself was engaged in commercial activities before he was called, there could be found many sorts of mercantile metaphors in the Qur'ān and the Hadīth. The main theme of this paper, however, is not to investigate probable historical origins or social sources of these metaphors. It is enough for our purpose here to point out merely the fact that there are a lot of mercantile metaphors in the creeds of Islam and that an exchange theory may be one of appropriate approaches to Islam from a sociological point of view. 
It is worth noting that although some material goods such as sacrificed animals or tangible offerings have been considered as typical gifts to God in early works of scholars who have analysed some socio-cultural aspects of magicoreligious phenomena through the framework of an exchange theory, we include not only some material goods but also non-material devotions or abstract ideas such as a pious behaviour or a earnest belief in Allah in the category of the gift to God, since according to the Islamic theology of the Last Judgement, a person's fate depends ultimately on an amount of good deeds done in this world based on his sincere worship toward Allah. In other word, his pious behaviours can be considered as gifts to Allah, and devine rewards to him as a return from Allah.

\section{Analysis - Four types of benefit-granting in Islam}

We start to provide a model of an exchange (fig. 1) which will be often referred in the following discussion. (2) This should be read that when $\mathrm{A}$ gives $\mathrm{x}$ to $\mathrm{B}$ as a gift, $\mathrm{B}$ receives it and then presents $\mathrm{y}$ to $\mathrm{A}$ as a return. In this case, it is not significant for our analysis to ask such questions as whether a relative value of $\mathbf{x}$ is greater than that of $\mathrm{y}$ or not, and whether a gift represents some material entity (like money, a sacrificed animal or an offering) or non-material invisible behavior or condition (like a belief, a happiness or a life).

In order to compose a typology, two elements in the model are specially taken out. Then we suppose two cases in each element. Firstly, to whom does an original giver [A] give a gift directly? It is assumed that the receiver [B] is Allah or a fellow Muslim, though in some of the latter cases the gift seems to be donated lastly to Allah. And secondly, when and where does the receiver [B] return a reward to A, either in this world or in the hereafter?

Combining two alternatives together, we gain four domains (see fig. 2), each of which is supposed to represent a type of exchange in Islam. We will examine them respectively in detail.

Type I (fig. 3): This type represents the case that a Muslim [A] directly gives a gift to Allah [B] and receives its return in the hereafter. A reward in this case is a sublime bliss in the hereafter as emphasized repeatedly in the Qur'ān. The obligatory conducts which are formally imposed on all Muslim such as daily prayers (salät), a fast (șawm) in the month of Ramadan or the other

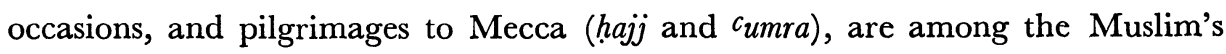


non-material gifts toward Allah, which are expected to obtain uncountable benefits for him in the hereafter as their return. A formula of the confession (shahāda) which a Muslim should repeat on any opportunity might be considered as one of such behaviors.

These are considered to be pious conducts which good Muslims naturally carry out in their daily life. As a result, they become "creditors", who firstly give a gift to Allah, and the latter as a "debtor", in His turn, affords them a blessed life in the hereafter. Since four of the five "pillars" in the Islamic creed are included in this type, it may be safely suggested that the idea of a benefit-granting in the hereafter has been legitimately emphasized in the formal theology of Islam.

A martyrdom in the way of a holy war ( $j i h \bar{a} d)$ might be also considered as one of the cases belonging to this type. Unlike the cases of a prayer, a fast, a pilgrimage and a confession mentioned above, in which a pious behavior is taken into account as a gift to Allah, not only a struggle in a holy war itself but also one's human life in this world may become a precious present to Him.

Type II (fig. 4): This type includes supplications of Muslim [A], who offers a gift to Allah [B], expecting a realization of some desirable results in this world. One of the instances belonging to this type of an exchange is $d u^{c} \bar{a}^{\prime}$ or a personal supplication, which is categorically distinguished from salät or an obligatory prayer. A Muslim can supplicate Allah to bless him before or after a prayer in a mosque or at any place. It is legitimate for him to seek after His favor in this world as well as in the hereafter. He may legitimately ask for Him to cure a disease or to let him succeed in business and so on as a reward to a pious believer. A prayer for rain-falling (șalät al-istisq $\bar{a}^{\prime}$ ) also belongs to this type, which has been carried out even in Saudi-Arabia, one of contemporary countries holding firmly the most rigorous sort of Islamic creed. The main purpose of all these forms of conduct is clearly to supplicate Allah for granting some benefits in this world in return for submissive behavior and an obedient attitude on the part of Muslims toward Him.

By contrast with the exchange of type I, in which a Muslim seeks after a generally happy life in the hereafter, in that of type II he asks Allah some particular desires such as a recovery from an illness, a success in a business or a rain falling as a reward. Particularizing an object of the supplication may be one of the characteristics which we will find in an exchange of the type IV, the other type in which a man wishes to gain a devine benefit in this world. 
Type III (fig. 5): This is a type, in which, though a gift from a man will be thought to be given in the last instance to Allah in the form of a submission to Him, it is a material one which is actually delivered to a fellow human being. In this case, a Muslim [A], who gives a gift directly to a fellow man [B1], will enjoy a benefit in the hereafter not from the receiver of the gift but from Allah [B2], who recognizes his good conduct as a "credit" to Him. We can safely call this type of an exchange as an "indirect exchange" between $\mathrm{A}$ and $\mathrm{B} 2$, and $\mathrm{B} 1$ as an intermediary.

An almsgiving ( $z a k \bar{a} t)$, which is one of the five pillars in Islam, and a voluntary charity (sadaqa), some examples of which are gifts of some amount of money or some portions of meat to the poor people on the auspicious occasions like a rite of passage or a festival ( $c i d$ or mawlid), might belong to an exchange of this type. Besides them, a public water supply (sabil) to a passer-by or a traveler, the remains of which we can still find in some parts of countryside of Egypt today, is one of the examples, too. So is a religious endowment (waqf), especially the so-called waqf khairi, which is considered formally as a pious donation toward Allah of a private property (in most cases, a plot of land and a building on it) and its utilization for public purposes such as facilities for the religion (a mosque or a religious school) or for a general welfare (a hospital or an orphanage).

Type IV (fig. $6 \& 7$ ): In this type of an exchange, a Muslim firstly gives a gift to a fellow man and, on its return, he will receive some benefits in this world. One of the most outstanding examples of this type is the practice of Muslims believing in Islamic saints. Though folk beliefs in Islamic saints are so complicated that they have to be investigated totally from various disciplines, we here try to analyze them from a perspective of an exchange theory and, therefore, concentrate on one of their essential aspects as a main subject of the study. There is a folk custom of visiting (ziyāra) a tomb or a shrine of a deceased saint to supplicate him; at a general level, in return for this, the visitor receives his blessing, and at a specific level, is relieved of sufferings such as sickness and barrenness, or succeeds in business or entrance examinations. Such practices, which have been found most of Muslim societies with some conspicuous exceptions (ex. Saudi-Arabia), resembles some of Japanese folk beliefs and customs, a chatacteristic of which is to supplicate deities for granting some divine benefit in this world.

From the perspective of an exchange theory, a significant issue here is who 
gives a benefit to a supplicant. Apparently it is taken for granted that a saint, who can work miracles (karämät) thanks to a blessing (baraka) given to him by Allah, grants a supplicant's request. It is a commonly held logic or an ideology that a saint himself has a supernatural power, through which he is able to carry out believers' wishes.

For example, W. S. Blackman, who published a detailed ethnography on folk beliefs among peasants of the Upper Egypt on the basis of her own fieldwork conducted in the 1920s, reported as follows.

"The people flock in crowds to these [saints'] tombs on certain days of the week - usually Thursdays or Fridays - generally to make some special request, or with the object of being freed from some disease, which they believe the sheikh can cure." [1968: 242, an emphasis added].

During a field research carried out among a rural area of the Lower Egypt on 1981-81, I visited a "servant of a saint" (khädim al-shaykh), who had supervised a shrine (maqām) of an Islamic saint named Shaykh Iraqi in a village near Benha city in the Qalyubiya Governorate. Although he was unfortunately out of the village on my visit, I interviewed his wife and son. As a response to my inquiry, she told me a story of a miracle the shaykh did recently, which was concerned with a supernatural cure for blindness. The story is that one of overseers $(k h \bar{u} l i \bar{l}$ affiliated to the large plantations possessed by Sayyid Marei, one of the political leaders after the revolution in 1952, was struck blind and the modern medical treatment had no effect on his recovery. One night the overseer dreamed of Shaykh Iraqi who gave him a cup of white liquid and he drunk it. When he got up in the next morning, his vision recovered. He exclaimed for a great joy "Salvation. Oh, Shaykh Iraqi" (madad, ya Shaykh Iraqi). He immediately went to Zagazig city to buy a cloth cover (kiswa) for the shaykh's tomb and came to the village to talk about the miraculous story. Handing over the cover to her (the wife of the servant of the shaykh), he asked her to put this new cover on the tomb of the Shaykh. For the overseer, it is the Shaykh who cured his disease and who had qualified to receive a gift from him as a return.

The religiously trained men appear to have a different opinion. When I had an interview with the Shaykh A. Atiya, the imam of the Ahmad Badawi mosque located in Tanta city of the Lower Egypt (on August, 1982), he recognized that, seeking various benefits, people visit the shrine of Ahmad Badawi, who is the founder of the one of the four influential Sufi orders and 
has been one of the most famous and revered saints in Egypt. But he insisted that "They come to the shrine of Ahmad Badawi not to supplicate him for granting them some benefits. They supplicate Allah in the pure place [the shrine of the saint] (yatlubūna min Alläh fi al-makān al-țähir)." He emphasized that it was Allah not the saint who could answer supplications from Muslims.

As time went by, however, he expressed his idea with a slightly different nuance. He said that when people visited the shrine for a supplication, "listening to their requests, the Shaykh Badawi himself supplicates Allah for granting their wishes, then they will be granted. Since the soul (rüh) of the Shaykh, who supplicated for their sake, is very pure (tähira), much purer than ours. The purer the soul is, the closer (aqrab) it is to Allah." Shaykh Atiya seems to recognize in this discourse an intercessory role of Shaykh Badawi between Allah and common Muslims.

This nuance which we could find in the discourses of the Shaykh Atiya is very significant for our analysis. The point is whether the wish of a supplicant would be granted by Allah through an intercession of a saint or without it. If a saint played no role in the supplication and it was a direct transaction between Allah and a Muslim, this would be the same type of an exchange as the Type II. On the contrary, if an intercessory role of a saint was recognized, it would be included in a new type of an exchange.

Even if we restricted our discussion to the latter idea of the Shaykh Atiya, that is an idea of recognizing a saintly intercession, there would be two logics or ideologies for explaining a benefit-granting in this world through a visit to a shrine of a saint. One is that through an intercession of a saint, Allah Himself would grant a wish of a supplicant, which was presented by the Shaykh Atiya. And the other, which the overseer, believing straightforwardly in the Shaykh Iraqi's miraculous power, expressed in his crying mentioned above, is that the saint not Allah makes him recover from a suffering. We may safely call the former as a Shaykh ideology and the latter as a popular ideology.

Fig. 6 represents a Shaykh ideology, while fig. 7 a popular ideology. In fig. 6, it is Allah [B2] who ultimately gives a benefit to a Muslim [A]. A saint [B1] acts only as an intercessor, who is not entitled to answer a supplication and is concerned in an exchange only as a spokesman for a supplicant.

It is noteworthy that fig. 6 is the same as fig. 5 except for the place and time in which a Muslim receives a divine benefit. Similarly fig. 3 and fig. 4 are identical but for where and when a divine benefit will be granted. 
To the contrary, in a popular ideology represented in fig. 7, a circle of an exchange is closed between a saint [B] and a Muslim [A]. This means that this transaction could be conducted and completed without Allah. Contrary to fig. 6, it is Allah not a saint who is a redundant.

Besides such rigorous interpretations of Islam as the Wahhābi-s, activities of Sufism and an existence of saints have been recognized as a legitimate part of the Islamic theology. It has been pointed out, however, that some aspects of popular activities, conceptions and practices of a Sufism and a saint veneration have been furiously condemned by some scholars $\left({ }^{c} u l a m a \bar{a}\right)$, some fundamentalists like the slafists and even some leaders of the Sufi orders as an illegitimate innovation $(b i d c a)$. In this paper, we have proposed two models of a reciprocal exchange on the basis of two different ideologies on folk beliefs in Islamic saints. One of them (fig. 6) represents an indirect exchange between Allah and a Muslim through an intercession of a saint. The other (fig. 7) actually indicates a direct exchange between a saint and his believer without any intervention of Allah. It is understandable, then, that some of the Muslims, especially who have learned Islam to a certain degree, have reproached severely such practices which continue to be carried out by common people, because a popular ideology of a saint veneration, as the opponents claim, seems to be against the creed of the oneness of Allah (tawhid). Replacing Allah by a human saint as a generous giver of a mundane benefit to them, people tend to venerate him in place of Allah. This is a seriously dangerous trend opposing directly to the creed of tawhid. Fig. 7 visualizes an ideological ground for some Mulsim intellectuals to critisize some aspects of popular beliefs in Islamic saints.

So far, we have intentionally excluded from our analysis one of the ideas which the Shaykh A. Atiya of the Badawi mosque expressed, and have come to the conclusion that a reciprocal exchange of the Type IV, represented by fig. 6 not by 7, would be considered as a legitimate exchange between Allah and Muslims. However, more rigorous conception of Islam, which refuses absolutely the idea of an intercession by a saint, seems to become more influential on general trends of thoughts in many Muslim societies nowadays. When I had an interview with one of the leaders of the Sufi orders in Egypt in 1987, he categorically denied a role played by any saint as an intercessor. $\mathrm{He}$ emphasized that a Muslim, who intends to visit some of the saints' shrines seeking a recovery from an illness, for example, should supplicate Allah not 
the saint buried in the tomb, as Shaykh Atiya firstly insisted. It is clear that some of the salafiya interpretations of Islam have an effect on not only some fundamentalists who decided to be millitant in the field of the political struggle but also on some of ulama and even Sufi-s who are generally thought to be conservatives and often to be opposed ideologically to such political radicals. This is a significant subject of study which we will examine in the other paper and it is enough here to suggest several types of a reciprocal exchange between God and men in Islam and their implications for some Islamic ideologies.

\section{Notes}

(1) The two figures connected by a hyphen represent respectively the number of the chapter (süra) and that of the verse (aya) in the Qur'an. I refered to G. Sale's "translation" of the Qur'an to English. (first published in 1896 and reprinted by the AMS Press, Inc., N. Y. in 1975)

(2) For this model of an exchange, I refered to F. Barth's work [1966: 13].

\section{References}

Barth, F. 1966: Models of Social Organization, London. Blackman, W. S. 1968: The Fellahin of Upper Egypt. London.

Mauss, M. 1923-4: Essai sur le don. L'Année Sociologique (seconde série) 1. 
fig. 1

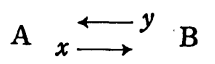

fig. 2

\begin{tabular}{|c|c|c|}
\hline $\begin{array}{c}\text { who is the } \\
\text { first receiver } \\
\text { when \& where a } \\
\text { return is granted }\end{array}$ & Allah & fellow muslim \\
\hline in the hereafter & I & III \\
\hline in this world & II & IV \\
\hline
\end{tabular}

fig. 3

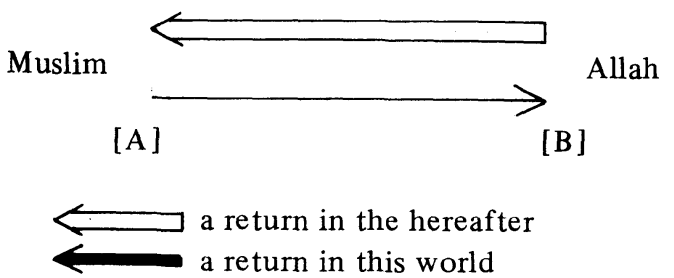

fig. 4 Muslim

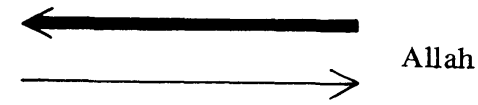

[A]

[B]

fig. 5 Muslim

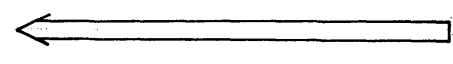

Allah

Muslim - - $\rightarrow$

[A]

[B 1 ]

[B2 ]

fig. 6

Muslim

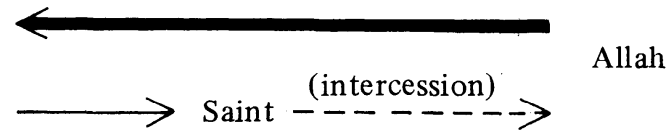

[A]

[B 1 ]

[B2]

fig. 7

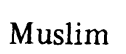

Saint

Allah

[A]

[B] 